Click www.researchjournal.co.in/online/subdetail.html to purchase.

RESEARCH P APER

International Journal of Agricultural Engineering | Volume 12 | Issue 1 | April, 2019 | 149-152

$\Rightarrow$ ISSN-0974-2662 $\square$ Visit us : www.researchjournal.co.in DOI: 10.15740/HAS/IJAE/12.1/149-152

\title{
Partial replacement of clay in bricks with municipal solid waste
}

\section{Abhishek Chanchal and Ritesh Jain}

Received : 16.01.2019; Revised : 01.03.2019; Accepted : 18.03.2019

See end of the Paper for authors' affiliation

Correspondence to :

\section{Abhishek Chanchal} Department of Agricultural Engineering, Punjab Agricultural University, Ludhiana (Punjab) India Email : Chanchalabhishek 1997@gmail.com
-ABSTRACT : Since ages, bricks have been made from clay. To save excessive usage of clay, one might use various types of waste products in the production of bricks with partial replacement of clay in the manufacturing process. Waste products might include plastic, glass, rubber, fly ash, construction material, sewage sludge and MSW. From past studies, it was found that wastes of various types such as municipal MSW incineration fly ash, paper sludge, agricultural waste, industrial waste (sewage, sludge and bagasse), sawdust wastes and limestone dust wastes and coconut shell powder have been used for the production of bricks by replacing clay partially. Bricks made from these wastes give satisfactory results. To examine the effect of MSW (powder form) in bricks we used MSW from waste treatment plant in this present study in different combinations as a partial replacement of clay. It's found upto 24 per cent MSW we may attain bricks of good quality reasonably.

- KEY WORDS : Bricks, Clay, Compressive strength, MSW, Waste

- HOW TO CITE THIS PAPER : Chanchal, Abhishek and Jain, Ritesh (2019). Partial replacement of clay in bricks with municipal solid waste. Internat. J. Agric. Engg., 12(1) : 149-152, DOI: 10.15740/ HAS/IJAE/12.1/149-152. Copyright@2019: Hind Agri-Horticultural Society. 